\title{
Personal Branding in Online Platform
}

\author{
Fahim Shaker, Reaz Hafiz
}

Lecturer, School of Business Studies, Southeast University, Dhaka, BANGLADESH

\begin{abstract}
Online personal branding connotes a way to communicate favorable attributes of an individual self in the online platform in order to differentiate oneself from others that will assist to attain the professional goals along with relational aspirations. Numerous studies focused on the importance of having a strong personal brand but mostly ignored the way of developing it in the virtual world. The objective of the paper is to explore various literatures from different disciplines to address the issue of developing a contextual framework of "construction of online personal brands." The study covers the area of personality dimensions, personal brand identity both core and extended, influence of surroundings in identity creation in the online environment, individual's image positioning and management etc.
\end{abstract}

Keywords: Online personal branding, personal branding, personal brand identity, image positioning

JEL Classification Code: M31; M37

\section{INTRODUCTION}

Branding is considered to be a recent addition in the distinct literature of marketing though it's mostly practice oriented and was largely ignored in the field of academics for a considerable time (Klein, 2002). It's considered to be a growing field faster than ever with some considerable gap in the various emerging branding theories (Hughes 2007, cited in Zarkada, 2012). Lair, Sullivan and Cheney (2005:311) described metaphor of branding "derives from the designated ownership of livestock". Branding was traditionally limited to consumer oriented products before the media expansion, and fragmented audiences impose several challenges to manage branding in different ways to cater specific or large number of audience. (Lair, et al. 2005). As a result, Branding efforts required management of certain favorable image and well crafted identity to sooth large numbers of audience (Cheney, 2000 cited in Lair et al. 2005). Today branding efforts are observed not only amongst consumer oriented products; it's well-practiced in the field of corporate communications, in the service industry and also amongst individuals described as 'Personal Branding.'

\section{OBjectives}

The main objective of this paper is to explore various literatures from different disciplines to address the issue of developing a contextual framework of 'construction of online personal brands.' For this purpose, a multi-disciplinary approach is undertaken to review the literature of 'online personal brands' borrowing from the disciplines of 'brand 
marketing' coupled with contemporary texts from sociology and psychology. Keeping focus on the core objective, this paper is going to highlight:

- Brand personality dimensions

- Discrepancy between human identity

- Relationship between online and offline identity

- $\quad$ Positioning of personal brand image \& techniques of handling it

\section{LITERATURE REVIEW}

The concept of personal branding is not unique; it is derived from the same basic concept of product development and promotional strategies transformed into personal development and self promotional efforts. Personal branding is considered to be an emerging new concept in the practice oriented marketing literature (Zarkada, 2012); it had been well practiced by various professionals on various grounds such as sportsmen, politicians, businessmen and musicians (Shepherd, 2005). The definition of personal branding is based on communication, for instance -how the personal brand is being communicated and presented to others by showcasing attributes of the individual self which will differentiate the personal brand from others (Arruda, 2003). According to Shepherd (2005), the importance of having a personal brand is well recognized due to the increasing pressure of globalization and emerging social media. Shepherd also argued that, the principles of personal branding do have similarities with the fundamentals of product marketing and branding procedure. In the process of personal branding, individuals are mostly engaged with self- marketing (Shepherd, 2005). However, Shepherd (2005) described personal branding from an employment viewpoint and described the potential benefits of obtaining personal brand building strategies to gain superiority in the job market. Clare (2002) described the importance of differentiate oneself from others through personal brand building in order to achieve professional goals and competitive edge. Mccorkle (et al, 1992) described the primary objective and importance of self-marketing to highlight recognized skills to accomplish professional goals. However, these studies were primarily based on the concept of personal branding to achieve professional goals and didn't mention the motivation of self-marketing or personal branding to achieve personal or social goals. If we consider online communication platforms or social network platforms as a market and the users of online communication platforms as brands, individuals are practically getting involved in the process of creating and promoting their personal brands which would serve as a potential for accomplishing relational goals. Labrecque, Markos \& Milne (2011) have argued that the virtual space provides different platforms for individuals to self-brand their own identity with the help of 'Web 2.0 technology. According to the authors, online personal websites and social media profiles can be well manageable by anyone without any prior technical knowledge through sophisticated Web 2.0 technology tools. Web 2.0 encourages individuals to provide user generated contents, upload pictures, text, videos and digital resumes and bio-data. (Labrecque et al. 2011). As a result, internet today has become an internet platform for maintaining personal brands.

The concept of personal branding was first introduced by Tom peters (1997) where he describes everyone to possess the power of being their own brand (Labrecque et al. 2011). There are other steam of work from some authors considered to be a pioneer in this field such as Montoya (et al 2002), Arruda (2003) and Dan Schwabel (2009) demonstrating the strength and potentials of constructing a strong personal brand. There are abundant articles, self-help books and magazines available in the internet from various marketing 
practitioners showcasing heavily on the importance of having a strong personal brand, how properly it should be constructed and communicated. However, the abundance of books and articles on personally branding rarely emphasize how personal brands are constructed in reality in different platforms with the challenge of maintaining authenticity within the brand. As we find, most of the literatures available on personal branding tend to be practical providing hints on how well it should be developed (Bendisch et al. 2007).

Critics of personal branding (Conley, 2008; Zarkada, 2012) have mostly rejected the abundant online materials of personal branding as they were overly manipulative, ambiguous and hardly suggest a cohesive theoretical framework on this concept. Therefore, it becomes imperative to address a theoretical framework within 'personal branding' which is cohesive with the academic literature.

Shepherd (2005), Winch and Webster (2012) argues that 'personal branding' literature in some ways adheres to the concept of 'product branding approach.' Shepherd (2005) also suggests that, the theory of human identity construction can also be discussed in the context of personal branding to explain how people construct their online personal identity.

\section{Methodology}

The nature of the study is exploratory. In the study, the authors collected data from secondary sources such as various journals, websites, magazines, publications, earlier research works, books. All the required information and references are attached in the reference section of the paper.

\section{RATIONALE OF THE STUdy}

In modern era the concept of personal branding is going to be viral. People now a day try to portray a positive self among the surroundings in order to get appreciation in the regular way of life. But most of the study regarding personal branding is directed towards the attainment of professional goals. It's an important limitation of 'personal branding' literature that it is served mostly for the attainment of professional goals and not for social or relational goals. The problem with the current body of literature is that the focus on how individuals develop their personal brands in virtual world is largely ignored while priorities were given more to the importance of having a strong personal brand. Focusing on this particular research gap, in the study authors concentrated their effort to find out the way people can ripen the brand identity by using online platform and positioning image through a genuine disclosure.

\section{Brand Personality to human Personality}

According to Aaker (1997), brand personalities are the set of personality dimensions relevant to the human characteristics associated with the brand. When brand is being conceptualized through product related attributes, brand is defined by its functional and emotional benefits along with quality serving the brand to be evaluated through consumer perspective. On the other hand, personality measures are set of dimensions that help the brand to self express them and to enable them to create their own identity (Heding, Knudsen and Bjerre, 2009). The brand personality features a brand's self-expression and symbolic, functional ability (Keller, 1993). In other words, there are personality dimensions of a brand that enables the brand to be performed as a 'self brand'. Literatures in the 'selfbrand' also support the notions of brand's personality features enabling the brand to 
express their identity, their ideal self or specific dimensions of the self (Malhotra, 1981; Belk, 1988; Kleine et al.1993-cited in Bendisch et al. 2007).

Jennifer Aaker's (1997) 'brand personality' literature contributes significantly to the previous literature of 'self-brand' process. There were 114 personality traits based on 37 brands and 631 subjects to describe brand personality dimensions. Aaker (1997) through her studies described five core dimensions of personality significant for understanding of self-branding process. The five personality dimensions are together called as 'Big Five.' These are - Sincerity, Excitement, Competence, Sophisticated and ruggedness. Varey (2002) explained these five personality dimensions with possible characteristics and examples which are presented below. These personality dimensions are significantly important to demonstrate the initial stage of 'personal branding' process.

\begin{tabular}{|lll|}
\hline Brand image & Characteristic & Example \\
\hline \multirow{2}{*}{ Sincerity } & Down to earth & Family-oriented, small-town, conventional \\
& Honest & Sincere, real, ethical, thoughtful \\
& Wholesome & Genuine, classic, old-fashioned \\
& Cheerful & Sentimental, friendly, warm, happy \\
Excitement & Daring & Trendy, exciting, flashy, provocative \\
& Spirited & Cool, young, lively, outgoing, adventurous \\
& Imaginative & Unique, humorous, surprising, artistic, fun \\
& Up to date & Independent, contemporary, innovative, aggressive \\
Competence & Reliable & Hard-working, secure, efficient, trustworthy, careful \\
& Intelligent & Technical, serious \\
& Successful & Leader, confident, influential \\
Sophisticated & Upper class & Glamorous, good-looling, pretentious, \\
& sophisticated \\
& Charming & Feminine, smooth, gentle, sexy \\
Ruggedness & Outdoor & Masculine, active, athletic \\
& Tough & Rugged, strong, no-nonsense \\
\hline
\end{tabular}

Figure 1: Five Personality Dimensions based on Aaker (1997) - source- Varey, 2002:155)

A brand is expected to attract its potential consumers through its association of personal characteristics. Consumers feel attachment to a brand because of certain attributes a brand develops through its personality (Evans et al. 2009). Similarly, in online personal branding approach, individuals are expected to carry certain meaning with their brand personality portrayal in order to associate with a group of people. For instance, an online personal brand in a social network that portrays him as athletic and extremely fond of physical exercise would like to associate himself with someone who possess similar brand personality and expected to feel a certain level of attachment with him. The initial motives behind objectifying a personality in an online personal brand profile is to find an association with other personal brands which has similar connections so that both can complement the ultimate objective of getting connected to each others. 


\section{Personal Brand IDENTIty}

Personal brand identity can be derived from the core concepts of 'brand identity.' According to Kapferer (1997:17)-" The brand is not just the product but it gives the product meaning and defines its identity in both time and space." Brand identity as described by Aaker (1996) are the unique sets of associations to address what the brand stands for and to convey brand promises to its customers and to stakeholders. Aaker (1996) describes brand identity as a combination of core and extended identity. The core identity of the brand features the brand's vision such as what the brand originally is and where/what it wants to be. The core identity of the brand also provides the reflection of the organization's strategy and tries to differentiate the brand to its customers by featuring the brand's unique associations. On the other hand, the extended identity provides the brand a sense of 'completeness' and supplements the brand's core identity in a way. (Aaker, 1996).

The extended brand identity can feature the personality dimensions of the brand to provide completeness. These personality dimensions attach certain meaning to the brand to supplement brand's core identity (Aaker, 1996). On one hand, there's core dimension of the brand that describes the brand's core attributes, quality or materialistic features. The extended identity adds flavor to the core identity and tries to define the brand based on it's characteristics. The fate of the brand is more dependent on its extended identity (Bendisch et al. 2007) such as- how the brand is actually being communicated to others have the larger impact than how the brand actually is. Therefore, marketers try to attach certain personality traits with a brand supplementing brand's core attributes, which theoretically is described as brand's extended identity.

A personal brand identity is significantly relevant to the concepts of 'human identity' (Shepherd, 2005). In the case of human identity construction, individuals emancipate their extended identities through the selection of socially desirable qualities or set of personal characteristics that attach certain meaning to the individual self (Markus \&Nurius, 1986). On the other hand, core identity in personal brand features what the individual is from inside, the actual reflection of self. For instance, an individual may try to promote himself as adventurous as a part of his extended identity since he wants himself to be seen by others as adventurous. Contrary to this, an individual's perception about self-being a monotonous person can be described as a core identity of his or her personal brand.

\section{ONLINE IDENTITY}

There had been much research on how people construct their identities in both offline and online environments (kozinet, 1997; kozinet, 2002). Online environment offers a wide range of platforms for formation of identities in order to establish or maintain social relationships such as social networking sites, multiplayer gaming, chat-rooms, online dating and matrimonial sites and many more ( Ribeiro, 2009). It's often argued that the formed online identities vary from each other's depending on the online platforms. Much of these relational developments in online environment are based on the pre-existing offline relationships; for instance- individuals connect with the people online who they know offline (Birnie and Horvath, 2002). Online dating sites and matrimonial web services differ from regular online platforms in this aspect since the pre-existing relationships with the potential audiences are mostly absent. However, perceptions from pre-existing relations with others influence self-construction of identity in such platforms.

Since identity is considered to be a truly social phenomenon (Mead, 1934 cited in Yurchisin, Watchravesringkan and McCabe, 2005) development process of an online 
identity is inspired by the feedbacks from others in offline environments. The feedback from others perform as catalysts to affect people's perception of themselves which inevitably contributes significantly in people's brand identity development in online platforms (Yurchisin et al. 2005). This is supported by earlier studies which describes that individuals examine their actions, cognitive values from the perspective of others (Mead, 1934; Goffman, 1990). Mead (1934) argued that the responses from individuals to the perspective of others are twofold. According to Mead, perspective of others that consist social, peers, and family members can be described as 'significant others.' The significant others have the higher amount of influence in daily lives and thus play a larger part in constructing human identity. On the other hand, individuals often comply with the norms and expectations of a community/society described as the response towards 'generalized others.' (Mead, 1934).

Yurchisin (et al. 2005) argues that the individuals re-create their personal brand identity in the online platforms based on the existing offline perceptions of self. According to Yurchisin (et al. 2005), identity re-creation is most likely to occur in online romantic relationship platforms since users often change their online identities in such platforms due to continuous online and offline feedbacks from others. The authors describe -

"It seems very likely that the process of identity re-creation may be occurring during the consumption of Internet dating services because individuals are encouraged by the Internet dating services to periodically "update" their profiles to reflect personal changes that have occurred since they first posted their profiles." (Yurchisin et al. 2005: 739).

\section{IDENTITY EMBODIMENT THROUGH TEXT AND IMAGE}

Self-creation of personal brand identity in profile based online communication platforms is twofold- identity embodiment through text based information and digitalized images. Identity embodiment through textual descriptions offer individuals to present detailed information highlighting their personal characteristics, demographic information, hobbies and ideal romantic partner preference (Whitty, 2007). Here individuals can preface 'anonymity' which allows to explore them over the internet or just to be themselves with authentic self-disclosure (Suler, 2004). These profiles may help individuals to explore and revise their identities through text or image manipulation (Yurchisin et al. 2005; Whitty, 2007). Online anonymity allows individuals to take immediate control of their identity by processing information consisting desirable qualities which can change offline perceptions of others about themselves. This is described as 'exploration techniques' (Yurchisin et al. 2005) providing individuals the possibility to explore 'the possible selves' and to validate these from both online and offline environment (Whitty, 2007).

On the other hand, individuals have the freedom to be less affected by the perceptions formed by others about selves in offline social environment and to engage in an authentic self- disclosure in online environments. Authentic self- disclosure in the online environment requires individuals to diminish or minimize the gap between his 'core identity' and 'extended identity' and to engage in fewer identity adjustments. According to Gibbs (et al. 2006), authentic self- disclosure guarantees more success in finding potential partners in dating networks.

\section{Personal Brand Image}

Similar to the concept of people brand identity, people brand image concept is needed to be complemented from the theoretical understanding of 'brand image' concepts. Keller (1993, cited in Lee et al. 2011: 1093) described brand image as "perceptions about a brand 
as reflected by the brand association held in consumer memory." Brand image is about brand's perception to its consumers (Aaker, 1996); consumer's thoughts and feelings about the brand (Roy and Banarjee, 2007), and mental image consumer's form about a brand sorting out the differences a brand has from others (Faircloth, 2005; cited in Lee, et al. 2011). Brand image is a combination of consumer's knowledge and beliefs about a brand's product and non-product related attributes (Lee et al. 2009). Keller (2003 cited in Bendisch et al. 2007:9) explained brand image to be combinations of different brand associations such as "user profile, purchase and usage situations, personality and values, as well as history, heritage and experience." These associations are considered to be part of brand identity as well as brand image. Therefore it can only be assumed that brand image consists of reflections of brand identity in consumer's mind (Bendisch et al. 2007).

'People brand image' concept can be derived from the brand image literature. Relating to the concepts of brand image and identity (Keller, 1993; Aaker 1996), human image refers to the perceptions of the individual from an outsider perspective for instance- how others think of him/her as a person. If we count an individual as a brand, the brand image explains mental image of the others (consumers) consisting of the knowledge and beliefs about the brand (human). The perceptions are based on the core attributes of the brand (core identity) and the extended attributes (extended identity). The extended identity plays a larger role in developing a personal brand image. However, it's discussed earlier that extended identity supplements individual's core identity (Aaker, 1996).

Aaker's (1997) brand personality research suggests that individuals have a desire to express their association with others externally that can be brands or groups. Therefore, it can be argued that the 'brand' can be served as a platform, for instance, individuals may try to associate brand when they try to present an attractive brand image to others. This process is two dimensional (Bendisch et al. 2007), for instance -individuals develop their self-image based on the mental modeling of him and individuals try to adopt an attractive or desirable image to others based on other's perception about him/her. The self- image or the mental model of self is influenced by the perceptions of the surroundings, similarly the mental model of self influences the way others perceive about the individual.

\section{People Brand Image Positioning}

In traditional brand building theory, positioning is about creating a perception about the brand in consumer's mind based on the brand's product related attributes such as price quality, durability exploring brand's functional association (Herrmann and Huber, 2000). Brand positioning strategy is sought by marketers to gain competitive advantage; therefore consumer marketing research mostly defined brand positioning strategy to instigate brand's utilitarian features. However, critics had argued that brands should not only be positioned based on the product related attributes, positioning a brand based on brand's symbolic association such as non product related attributes can give a brand superior competitive advantage. (Poisez, 1989). The basic concept of brand positioning whether it's highlighted on functional features or non product related attributes is to differentiate the brand from competing others. In the process of differentiating the brand from competing others, brand creators make attempts to construct a favorable image of the brand to the consumer's mind (Bendisch et al. 2007). People brand image positioning can significantly differ from regular product brand image positioning strategy since product brand related strategy mostly aims to establish the brand's image based on the functional /tangible features. On the other hand, it's more unlikely to find tangible features in people brands, especially since people brands 
are built on human personality, and they are most likely to self express their brand unlike product brand's positioning which are conducted by the brand creators.

Typically, people branding concepts are limited to popular celebrity endorsements, marketing professionals and features only show celebrities being positioned by others as popular brands (Shepherd, 2005; Rein et al. 2006). Since people brand management literature is a very much work in progress ( Bendisch et al. 2007), scholars are yet to recognize general people as 'brand' and their brand development process such as how people self express their brands. Borrowing from the literature of 'brand image' (Aaker, 1996) and 'brand positioning' (Kapferer, 1997), individuals brand positioning can be described as a process to generate a desired 'brand image' reflecting the personal brand identity. The main theme of brand positioning is to differentiate the brand from others (Kapferer, 1997), therefore, individuals can rely on single or multiple attributes to differentiate him/her as a brand (Herbst, 2003 cited in Bendisch et al. 2007).

A number of theories are significantly relevant to describe people brand positioning. Some of these are explained here.

\section{IMPRESSION MANAGEMENT}

Impression management is described as conscious efforts to control, regulate and manipulate behaviors in order to impose a favorable impression to a targeted audience (Rosenberg and Egbert, 2011). Impression management is based on interactions, people engage in "strategic actions to create and maintain a desired image." (Goffman, 1959 cited in Rosenberg et al. 2011:2). People engage in various self- presentation tactics to maintain a desired image to others to achieve short or long term interpersonal goals. Considering people as brands, their self- presentation/impression management tactics in various interactions can be defined as attempts to position their personal brands in order to impose favorable brand image.

Zhao (et al. 2008) cited in Rosenberg( et al. 2011) described individual's attempts to maintain impression can happen both in face to face and computer mediated environments. The main motivations for maintaining impressions in online environments such as social media or dating networks are regarded as the possibility of future interactions or relational goals both short and long term (Rosenberg et al. 2011). Previous studies on online impression management suggest that, impression management tactics are based on physical attractiveness (Toma, Hancock and Ellison, 2008); social attractiveness such as numbers of friends in Facebook (Walther et al. 2008) etc.

Impression management tactics are goal oriented and Rosenberg (et al. 2011) described these goals as primary and secondary goals. These can be treated as important metaphors in people brand management concept such as the underlying motivations behind personal brand positioning. Primary goals are described as influence goals to demonstrate behavioral change in other persons by imposing favorable image. Secondary goals are described as an extension of primary goals in impression management and these can be of four types-

- Interaction oriented - "desire to maintain or increase attention, emotional support or engage in social comparison" (Dillard, 1990 cited in Rosenberg et al, 2011:3).

- Identity goals - desire to maintain a self- image/concept

- Personal resource goals- desire of materialistic possession, physical or mental assets.

- Arousal management goals- desire to operate under comfort zone within a defined boundary. (Rosenberg et al. 2011). 


\section{High Versus Low Self Monitoring}

Individuals regulate, control and maintain their behavior to impose a desirable self image to others which is described as 'self monitoring.' (Rosenberg et al. 2011). Individuals riding high on self- monitoring have a high level of adjustability to different social situations, and skilled at controlling images. They are described as highly image conscious, sensitive to social norms and engage in behaviors that are socially appropriate (Mehra et al. 2001). High self- monitors are expected to have high level of judgmental capability on what to express and what not to be based on cultural acceptability context. Therefore, they are expected to be engaged in image manipulation to impose a more favorable picture of themselves to others (Mehra et al. 2001). On the other hand, low self- monitors are less sensitive about the social cues, having a low level of understanding about the acceptability of their self- expressions and considered to be less image sensitive (Rosenberg et al. 2011). They can be regarded as less cautious in their self- presentation tactics and may not have highly controlled behavior in social networks. However, they are likely to be more authentic and less image manipulative when it comes to presenting themselves in different networks.

The way individuals monitor their self- presentation tactics can have significant influence on how they position their brand. Based on these behavioral characteristics, individuals manage and position their brands which may or may not impose a desirable image to others.

\section{CONCLUSION}

As online personal branding concept is engaged mostly with self- marketing and blending of core identity with the support of extended identity, people try to communicate a positive image with the aim of getting recognition from significant others along with generalized others. The personal branding experts (Peters, 1997; Montoya et al. 2002) suggest that the online personal brands are to be built on the quintessential aspect of human personality and it should highlight the strength, goals and personality in a persuasive manner. In order to make authentic disclosure in online platform, individuals should engage in self- assessment and strive to find out significant aspects. Favorable impression in the online platform among the target audience can fulfill self-esteem need of individual both in online and offline environment, which consequence is a successful personal branding.

\section{REFERENCES}

Aaker, D.A. (1996) Building Strong Brands. New York: The Free Press

Aaker, J. (1997) “Dimensions of Brand Personality." Journal of Marketing Research, 19(August): 347-356.

Ahmed AA and Siddique MN. 2013. Internet Banking Espousal in Bangladesh: A Probing Study Engineering International, 1, 40-47.

Alam MA and Islam MM. 2012. Plan and Policies for Success in the Business World: A Conceptual Study ABC Journal of Advanced Research, 1, 60-69.

Arruda, W. (2003), An Introduction to Personal Branding: a revolution in the way we manage our careers. Accessed May 28, 2014, from <www.reachcc.com $>$

Awan AG and Khan RE. 2014. The Enigma of US Productivity Slowdown: A Theoretical Analysis American Journal of Trade and Policy, 1, 7-15.

Bendisch, F, F., Larsen, G and Trueman, M (2007). Branding People: Towards A Conceptual Framework. Bradford University School of Management, UK. Working Paper No 07/22, accessed May 28, 2014 from <http://info.brad.ac.uk/acad/management/external/pdf/workingpapers/2007/Booklet_07-22. Pdf $>$ 
Birnie, S. A., \& Horvath, P. (2002). Psychological predictors of Internet social communication. Journal of Computer-Mediated Communication, 7 (4)

Chowdhury AH, Chowdhury MS and Imran M. 2013. Branding strategies for service firms- a study on the selected Internet Service Providers (ISPs) in Bangladesh Asian Business Review, 2, 47-53.

Clare, A (2007). Brand me (making your mark to succeed). Journal of marketing.

Conley, L. (2008). OBD: Obsessive Branding Disorder. Philadelphia, PA, Public Affairs.

Dilip Roy, Saikat Banerjee, (2007) "CARE-ing strategy for integration of brand identity with brand image", International Journal of Commerce and Management, Vol. 17 Iss: 1/2, pp.140 - 148

Evans, Martin, Jamal, Ahmad \& Foxall, Gordon (2009). Consumer Behavior, 2nd edition, Chichester: John Wiley.

Fatema M, Azad MA and Masum AK. 2013. Impact of Brand Image and Brand Loyalty in Measuring Brand Equity of Islami Bank Bangladesh Ltd. Asian Business Review, 2, 42-46.

Gibbs, J. L., Ellison, N. B., and Heino, R. D. (2006). Self-presentation in online personals: The role of anticipated future interaction, self-disclosure, and perceived success in Internet dating. Communication Research, 33 (2), 152-177

Goffman, E. (1990) the Presentation of Self in Everyday Life, London: Penguin

Heding, T., Knudsen F., C., \& Bjerre, M. (2009). Brand Management - Research, theory and Practice. New York, USA: Routledge

Hermann, A., Huber, F. (2000), Value-oriented Brand Positioning, The International Review of Retail, Distribution, and Consumer Research, Vol. 10, No. 1, pp. 95-112

Hsiang-Ming Lee, Ching-Chi Lee, Cou-Chen $\mathrm{Wu},(2011)$ "Brand image strategy affects brand equity after M\&A," European Journal of Marketing, Vol. 45 Iss: 7/8, pp.1091 - 1111

Islam MS. An Evaluation of Determining the Critical Success Factors for Implementing Total Quality Management Asian Accounting and Auditing Advancement. 2014;4(2):7-17.

Jiang J. 2014. The Study of the relationship between Leadership Style and Project Success American Journal of Trade and Policy, 1, 51-55.

Kapferer, J.-N. (1997) Strategic Brand Management. Creating and Sustaining Brand Equity Long term, 2ndEdition. London: Kogan Page.

Keller, K.L. (1993) "Conceptualizing, Measuring, and Managing Customer-Based Brand Equity." Journal of Marketing, 57(1): 1-22.

Klein, Naomi (2002) "The Failure of Brand USA: Why the Bush Administration Can't Sell America Abroad" In These Times, April 15.

Kozinets, Robert V. (1997) “'I Want To Believe': A Netnography of The X-Philes' Subculture of Consumption," Advances in Consumer Research, Volume 24, ed., Merrie Brucks and Deborah J. MacInnis, Provo, UT: Association for Consumer Research, 470-475.

Kozinets, Robert V. (2002), “The Field behind the Screen: Using Netnography for Marketing Research in Online Communities," Journal of Marketing Research, 39 (February), 61-72

Labrecque, Lauren I., Ereni C. Markos, and George R. Milne (2011), “Online Personal Branding Processes, Challenges, and Implications," Journal of Interactive Marketing, 25 (1), 37-50.

Lair, D.J., K. Sullivan and G. Cheney. 2005. Marketization and the recasting of the professional self: The rhetoric and ethics of personal branding. Management Communication Quarterly 18: 307-43.

M. T. Whitty, A. J. Baker, \& J. A. Inman (Eds.), Online matchmaking (pp. 57-69). Houndsmills: Palgrave Macmillan.

Markus, Hazel and Paula Nurius (1986), “Possible Selves," American Psychologist, 41 (9), 954- 969.

McCorkle, Denny E., Joe F. Alexander, and Memo F. Diriker (1992), “Developing Self-Marketing Skills for Student Career Success," Journal of Marketing Education, 14 (1), 57-67.

Mead, George H. (1934), Mind, Self, and Society, Chicago: The University of Chicago Press 
Mehra, A., Kilduff, M., and Brass, D.J. 2001. The social networks of high and low self-monitor: Implications for workplace performance. Administrative Science Quarterly, 46: 121-146

Montoya, P. and T. Vandehey (2002). The Personal Branding Phenomenon: realize greater influence, explosive income growth and rapid career advancement by applying the branding techniques of Oprah, Martha and Michael. Beaverton, OR, Personal Branding Press Publishing

Nasr DM, Mahmoudzadeh M, Mousavi S, Alikhani EA. Brand Making Process in B2B Companies (Case Study: Tam Iran Khodro Company) Asian Accounting and Auditing Advancement. 2014;4(1):44-50.

Ogunyomi, Olatunji O, Daisi, Richard O and Adebola R. 2013. Economic Globalization, Income Inequality and Economic Growth in Nigeria: A Static Data Analysis ABC Journal of Advanced Research, 2, 55-68.

Peters, T. (1997) "The brand called you", Fastcompany.com; accessed May 28, 2014 from http://www.fastcompany.com/magazine/10/brandyou.html

Poiesz, T. (1989). The image concept: its place in consumer psychology, Journal of Economic Psychology, Vol. 10, 457-72

Rein, I., Kotler, P. and Stoller, M. (2006) High Visibility: The Making and Marketing of Professionals into Celebrities, 3rd Edition. Lincolnwood: NTC Business Book

Ribeiro, José Carlos. (2009) the increase of the experiences of the self through the practice of Multiple virtual identities. Psychology Journal; Vol. 7 Issue 3, p291-302

Rosenberg, J. and Egbert, N. (2011), Online Impression Management: Personality Traits and Concerns for Secondary Goals as Predictors of Self-Presentation Tactics on Face book. Journal of Computer-Mediated Communication, 17: 1-18. Doi: 10.1111/j.1083-6101.2011.01560.x

Schawbel, D. (2009). Me 2.0: Build a powerful brand to achieve career success. Kaplan Publishing, Inc. New York.

Shepherd, I.D.H. 2005. From cattle and coke to Charlie: Meeting the challenge of self marketing and personal branding. Journal of Marketing Management 21: 589-606

Suler, J.R. (2004). The online disinhibition effect. Cyber Psychology and Behavior, 7, 321-326.

Tinne WS. 2013. Nation Branding: Beautiful Bangladesh Asian Business Review, 2, 31-36.

Toma, C., Hancock, J. and Ellison, N. (2008). Separating Fact from Fiction: An Examination of Deceptive Self-Presentation in Online Dating Profiles. Personality and Social Psychology Bulletin 34, 1023-1036.

Urdziková J, Jakábová M, Prajová V. Information Security Management System in Terms of Business Practice in Slovakia Asian Accounting and Auditing Advancement. 2014;4(1):34-43.

Vary, R J. (2002) Marketing Communication: Principles and Practice, Routledge, ISBN 041523039 X

Walther, J. B. (2007). Selective self-presentation in computer-mediated communication: Hyper personal dimensions of technology, language, and cognition. Computers in Human Behavior, 23, 25382557

Whitty, M. T. (2007). The art of selling one's self on an online dating site: The BAR approach.

Winch, Alison and Webster, Anna (2012). "Here comes the brand: Wedding media and the Management of transformation" Continuum: Journal of Media \& Cultural Studies, 26(1), 51-59.

Yurchisin, J., Watchravesringkan, K., \& McCabe, D. B. (2005). An exploration of identity recreation in the context of Internet dating. Social Behavior and Personality, 33(8), 735-750.

Zhao, S., Grasmack, S., \& Martin, J. (2008). Identity construction on Face book: Digital Empowerment in anchored relationships. Computers in Human Behavior, 24, 1816-1836. 
Publish online and print version both 